\title{
Prevalence and severity of early childhood caries in malnourished children in Mendoza, Argentina
}

\author{
Claudia N. Fernández', María I. Borjas², Salvador D. Cambría-Ronda', Walther Zavala ${ }^{3}$ \\ 1. Universidad Nacional de Cuyo, Facultad de Odontología, Cátedra de Odontopediatría, Mendoza, Argentina \\ 2. Universidad Nacional de Cuyo, Facultad de Odontología, Cátedra de Cátedra Diagnóstico Social y Clínico Preventivo, \\ Mendoza, Argentina \\ 3. Universidad Nacional de Cuyo, Facultad de Odontología, Cátedra de Histología y Embriología general y especial, \\ Mendoza, Argentina
}

\begin{abstract}
The aim of this correlational, descriptive, cross-sectional study was to describe the pathological profile of Early Childhood Caries (ECC) in malnourished children who attended two centers for prevention and treatment of child malnutrition in Mendoza, Argentina. The study included 145 children aged 12 to 71 months, with prior parental consent, and recorded dmft and dmfs according to ICDAS II 2 to 6 and 4 to 6 active caries categories, age and severity of caries experience. Parametric and non-parametric statistics were applied with $p=0.05$. Caries prevalence for enamel and dentin lesions was 48.2\%, declining to $35.2 \%$ when only dentin lesions were considered (dmft 4-6). The following means were found for dmft and dmfs: dmft 2-6 $2.10 \pm 3.31$, with " $d$ " $2.03 \pm 3.24$; dmfs $3.07 \pm 6.1$ with " $d$ " $2.91 \pm 6.1 ; d m f t 4-61.21 \pm 2.46$ with " $d$ " $1.14 \pm 2.37$; dmfs $4-61.98 \pm 5.14$ and " $d$ " $1.86 \pm 5.06$. There were statistically
\end{abstract}

significant differences between dmft 2-6 and dmft 4-6. Active enamel lesions (ICDAS II active categories 2 and 3) accounted for $37 \%$ of total lesions. Active lesions type 5 were the most frequent. The indicators for dental status and severity of caries experience increased with age, both with moderate positive correlations. Conclusions: Malnourished children under six years old studied in Mendoza presented comorbidity with ECC. Dental status worsened with age. The values for caries indicators demonstrated the weight of caries diagnoses in early stages and the importance of providing preventive measures and systematic monitoring during these children's early years of life..

Received: August 2020; Accepted: October 2020.

Keywords: early childhood - caries - malnutrition.

\section{Prevalencia y severidad de caries de la infancia temprana en niños con desnutrición infantil de Mendoza, Argentina}

\section{RESUMEN}

El presente estudio descriptivo transversal correlacional tuvo como objetivo describir el perfil de patología de la Caries de Infancia Temprana (CIT) en niños con desnutrición infantil asistentes a dos centros de prevención y tratamiento de la desnutrición infantil, en Mendoza, Rep. Argentina. Sobre un total de 145 niños entre 12 y 71 meses de edad, previo consentimiento parental, se registraron dmft y dmfs según categorías de caries activas ICDAS II 2 a 6 y 4 a 6; edad, y severidad de experiencia de caries. Se aplicó estadística paramétrica y no paramétrica con nivel de $p=0,05$. La prevalencia de caries para lesiones de esmalte y dentina fue del 48,2\% disminuyendo a un 35,2\% cuando se consideraron solo lesiones en dentina (dmft 4-6). Se hallaron las siguientes medias para dmft y dmfs: dmft 2-6 2,10 $\pm 3,31$, con " $c$ " de de 2,03 $\pm 3,24$; dmfs de 3,07 $\pm 6,1$ con "c" de 2,91 \pm 6,1; dmft 4-6 de 1.21 $\pm 2,46$ con "c" de 1,14 $\pm 2,37$; $d m f s$ 4-6 de 1,98 $\pm 5,14 y$ "c" de 1,86 \pm 5,06. Las diferencias observadas entre dmft 2-6 y dmft 4-6 fueron estadisticamente significativas. Las lesiones activas de esmalte (categorías 2 y 3 activas de ICDAS II) constituyeron 37\% del total de lesiones. Las lesiones activas tipo 5 fueron las más frecuentes. Los indicadores de estado dental y de severidad de experiencia de caries aumentaron con la edad, hallándose correlaciones positivas moderadas para ambas variables. Conclusiones: Los niños menores de seis años con desnutrición infantil estudiados en Mendoza, presentaron co- morbilidad con CIT. El estado dental empeoró con la edad. Los valores encontrados de los indicadores de caries demostraron el peso del diagnóstico de caries en sus estadios iniciales y la importancia de arribar con medidas preventivas y seguimiento sistemático en los primeros años de vida de estos niños.

Palabras clave: infancia temprana - caries - desnutrición. 


\section{INTRODUCTION}

Early childhood caries (ECC) is a relevant public health problem ${ }^{1}$. It has been defined as the presence of one or more decayed, missing (due to caries) or filled teeth in children 71 months of age or younger ${ }^{2}$. With the addition of an unfavorable systemic condition such as child malnutrition, ECC acquires further meaning in terms of risk factors and complications.

Child malnutrition, according to the United Nations Children's Fund (UNICEF), is "the outcome of insufficient food intake (in quantity and quality), the lack of adequate care and infectious diseases". Deficient nutritional status impacts stature (chronic malnutrition) and weight (acute malnutrition), causing delayed growth and affecting the child's physical and mental development ${ }^{3}$.

Child malnutrition contributes new forms of severity to ECC. Family and community socioeconomic variables have been included as potentiators of the severity and course of early childhood caries ${ }^{1,4-6}$, and it has been suggested that socioeconomically disadvantaged children are more vulnerable. In situations of poverty, the variable "malnutrition" is often added to the complex etiological panorama of ECC, thus affecting a disadvantaged social group that has barriers to access to both preventive and curative healthcare ${ }^{7,8}$. Malnutrition causes alterations in tooth development, leading to defects in enamel development and saliva composition through alteration of protein synthesis or mineral availability 9-11. This is why, in 2012, a new category was proposed for ECC associated to hypoplasia caused by nutritional deficiencies in early childhood stages ${ }^{12}$. The comorbidity of ECC and childhood malnutrition has been studied, defining nutritional status by means of several anthropometric measurements and caries prevalence with the $\mathrm{dmft}$ index. Different studies have reported varying results:

A study in India in 2014 related body mass index (BMI) to dmft, and although it found no significant association between them, the group of children with low weight had the highest caries prevalence ${ }^{13}$. Another study in Brazil in 2014 used WHO 2006 growth standards and found a statistically significant association between ECC and severe and mild malnutrition, though not between ECC and moderate malnutrition $^{14}$. In Cartagena, Colombia in 2009, children with chronic childhood malnutrition were found to have $82 \%$ caries prevalence and increased fluorosis ${ }^{15}$. In Argentina, there are few studies on populations of malnourished children. One study relating saliva flow to nutritional status in overweight children analyzed a sample of 60 preschoolers in areas adjacent to Buenos Aires city, reporting that 5\% of children were underweight according to $\mathrm{BMI}^{16}$. In Barranqueras, Chaco, in 2007, 59 children were studied, finding differences between malnourished and normally nourished children regarding caries indices, delayed eruption chronology and increase in frequency of hypoplasia ${ }^{17}$.

Many studies do not include the diagnosis of enamel lesions in the "decayed" component of indicators. As systematic review of caries in relation to body mass index reports this problem and, in order to avoid discrepancies in caries diagnostic criteria, recommends the inclusion of more sensitive systems such as ICDAS II (International Caries Detection and Assessment System) ${ }^{18}$ and more studies in children under 6 years old ${ }^{19}$. There are data on caries prevalence in low socioeconomic level preschoolers for Greater Mendoza, reporting 50.2\% caries prevalence (including enamel lesions) for children under 6 years old ${ }^{20}$. To date, no study has related ECC to child malnutrition in Mendoza Province.

Accordingly, the aim of this study is to describe the frequency and severity of ECC and possible associations among variables in children with chronic and acute child malnutrition, aged 12 to 71 months in Greater Mendoza, Argentina, including both dentin and enamel lesions.

\section{MATERIALS AND METHOD}

A descriptive, cross-sectional, correlational study was performed using an intentional sample of 145 children diagnosed with chronic or acute child malnutrition, aged 12 to 71 months, who attended the Las Heras Center for Human Promotion and Prevention of Child Malnutrition, (Centro de Prevención de Desnutrición Infantil y Promoción Humana de Las Heras) and the Teresa de Calcuta Hospital of the Cooperative Foundation for Child Malnutrition (Fundación Cooperadora de la Desnutrición Infantil [CONIN]) in Mendoza during 2017 and 2018. Nutritional status diagnosis was obtained as secondary data contained in institutional Clinical Histories, determined as z-score for weightfor-height, weight-for-age, height-for-age, BMI-forage and head circumference-for-age, and processed in the ANTRHO system (WHO) ${ }^{21}$. 
The study included all children whose parents or legal guardians provided written consent to participate in the project and excluded from the sample any children with reported comorbidity with diagnosed systemic diseases or whose behavior made it impossible to perform the practices. For ethical reasons, all children in the sample were included in an oral healthcare program. This project was approved by the Ethics and Research Committee of the University Hospital at Cuyo National University, under the Minutes of said Committee dated March 3, 2017. The following variables were considered:

Age categories in months: 12 to 23 months; 24 to 35 months; 36 to 47 months; 48 to 71 months.

Dental status: recorded according to $\mathrm{dmft}$ and $\mathrm{dmfs}$ indices ${ }^{22}$, butincluding within the category "decayed" ("d") non-cavitated enamel lesions (visible without drying) and cavitated enamel lesions, according to ICDAS II 2 to 6 active categories ${ }^{18}$. Two levels of analysis were used: 1) including only dentin lesions: dmft 4-6 and dmfs 4-6, and 2) considering enamel and dentin lesions: dmft 2-6 and dmfs 2-6.

Severity of caries experience was recorded by dividing it into four categories for the dmft index, as follows: $\mathrm{dmft}=0 ; \mathrm{dmft}: 1,2,3 ; \mathrm{dmft}: 4,5,6 ; \mathrm{dmft}: 7$ or more, both for "d" 2-6 and "d" 4-6.

Clinical examination was conducted by two calibrated researchers $($ Kappa $=81 \%)$ using the visual method applying the ICDAS II criterion for diagnosis and activity. Data were analyzed statistically using SPSS software version 17.0. Central tendency and frequency distribution measures were applied. Non-parametric tests were used with significance level $\mathrm{p}=0.05$ : Wilcoxon rank test to compare dmft 2-6 to dmft 4-6 and dmfs 2-6 to dmfs 4-6, and categories of severity of caries experience dmft 2-6 and dmft 4-6; KruskalWallis test and Spearman correlation coefficient to establish associations and correlation between results of dmft 2-6 and age; and chi-square test and Spearman correlation coefficient to study severity of caries experience according to age categories.

\section{RESULTS}

Distribution according to age groups was even $\left(\mathrm{x}^{2}=2.44 ; \mathrm{p}=0.485\right)$. The Kolmogorov-Smirnov test showed that the variables $\mathrm{dmft}$ and $\mathrm{dmfs}$ did not follow normal distribution, therefore non-parametric tests were applied to contrast the variables $(\mathrm{dmft}$ 2-6: $\mathrm{Z} \mathrm{KS}=3.17, \mathrm{p}=.000$; and $\mathrm{dmfs} 2-6: \mathrm{Z} \mathrm{KS}=3.73$, $\mathrm{p}=.000)$

\section{Dental status indicators}

Caries prevalence found for malnourished children was $\mathbf{4 8 . 2 \%}$ when enamel and dentin lesions were considered. This prevalence declined to $\mathbf{3 5 . 2 \%}$ when only dentin lesions were considered $(\mathrm{dmft}$ 4-6).

Mean dmft 2-6 was $2.10 \pm 3.31$ with very high disease burden denoted by a " $\mathrm{d}$ " component of $2.03 \pm 3.24$. The indicator behaved similarly when analyzed per surface, with dmfs $3.07 \pm 6.1$ and "ds" $2.91 \pm 6.1$. For dmft 4-6, values were $1.21 \pm 2.46$ with a "d" component of $1.14 \pm 2.37$. For dmfs 4-6, values were $1.98 \pm 5.14$ and its " $\mathrm{d}$ " component was $1.86 \pm 5.06$ (Table 1).

Wilcoxon rank test was used to compare $\mathrm{dmft}$ 2-6 to dmft 4-6 and dmfs 2-6 to dmfs 4-6, finding a significant difference between both pairs of variables, which shows that indicators that include enamel lesions are significantly higher than those that only consider dentin lesions (dmft: $\mathrm{Z}=-6.69 ; \mathrm{p}=$ .000 ; dmfs: $Z=-6.67 ; p=.000)$.

\section{Types of caries lesions according to ICDAS II active categories}

Active enamel lesions observed in this study (ICDAS II active categories 2 and 3) accounted for $37 \%$ of total lesions. Active lesions type 5 were the most frequent (32.1\%) (Fig. 1). In the first age category, $80 \%$ corresponded to enamel lesions.

\section{Severity of caries experience}

For both levels of analysis, severity of caries experience showed the highest percentages for the categories dmft 2-6 and 4-6 =0 and dmft 2-6 and 4-6: 1,2 and 3.

Significant differences were found between the categories for severity of caries experience dmft 2-6 and $\mathrm{dmft} 4-6$, increasing the values $=0$ when only dentin lesions were considered, and increasing the values 4, 5, 6 and 7 or + when enamel lesions were included in the indicator (Wilcoxon rank test $Z=$ -6.04; $\mathrm{p}=.00$ ) (Table 2).

Dental status according to age categories: Dental status indicator was taken as dmft 2-6 in order to include in the analyses all categories of caries lesions. Values for $\mathrm{dmft}$ were $0.11 \pm 0.39$ from 12 to 23 months; $1.38 \pm 2.36$ from 24 to 35 months; $2.41 \pm 2.44$ from 36 to 47 months and $4.53 \pm 4.62$ from 48 to 71 months (Table 3 ). 
Table 1. Descriptive statistics for dmft and dmfs 2-6 and 4-6 in malnourished children in Mendoza

\begin{tabular}{|c|c|c|c|c|c|}
\hline & Mean & $\begin{array}{l}\text { Standard } \\
\text { Error }\end{array}$ & $\begin{array}{l}\text { Standard } \\
\text { Deviation }\end{array}$ & Minimum & Maximum \\
\hline decay t 2-6 & 2.03 & .270 & 3.248 & 0 & 17 \\
\hline indicated extraction t 2-6 & .01 & .007 & .083 & 0 & 1 \\
\hline filled $t 2-6$ & .06 & .025 & .307 & 0 & 2 \\
\hline dmft $2-6$ & 2.10 & .275 & 3.317 & 0 & 17 \\
\hline decay s 2-6 & 2.95 & .507 & 6.101 & 0 & 40 \\
\hline indicated extraction s2-6 & .03 & .034 & .415 & 0 & 5 \\
\hline filled s 2-6 & .07 & .032 & .385 & 0 & 3 \\
\hline dmfs 2-6 & 3.07 & .514 & 6.188 & 0 & 40 \\
\hline decay t 4-6 & 1.14 & .197 & 2.371 & 0 & 14 \\
\hline indicated extraction t4-6 & .01 & .007 & .083 & 0 & 1 \\
\hline filled $t 4-6$ & .06 & .025 & .307 & 0 & 2 \\
\hline $\mathrm{dmft} \quad 4-6$ & 1.21 & .205 & 2.469 & 0 & 14 \\
\hline decay $s 4-6$ & 1.86 & .421 & 5.064 & 0 & 34 \\
\hline indicated extraction t 4-6 & .03 & .034 & .415 & 0 & 5 \\
\hline filled s 4-6 & .07 & .032 & .385 & 0 & 3 \\
\hline dmfs 4-6 & 1.98 & .427 & 5.146 & 0 & 34 \\
\hline
\end{tabular}

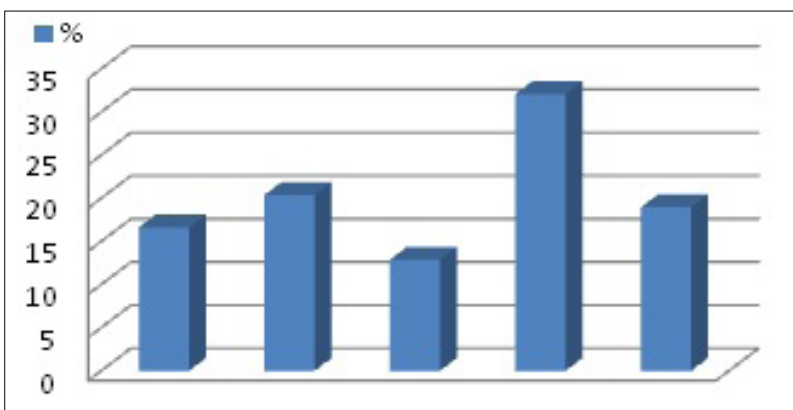

ICDAS 2 ICDAS $3 \quad$ ICDAS 4 ICDAS 5 ICDAS 6

Fig. 1: Percentage of active lesion categories according to ICDAS II in malnourished children in Mendoza.

The Kruskal-Wallis test $(\mathrm{KW}=45.79 ; \mathrm{p}=0.00)$ confirmed that there are significant differences between the results of dmft 2-6 and children's age in the study.

The Spearman correlation coefficient between dmft 2-6 and age categories in months was positive but moderate (Spearman's Rho $=0.561 ; \mathrm{p}=0.00$ ), corroborating the tendencies described previously.

\section{Severity of caries experience according to age categories}

A statistically significant association was found between the categories of $\mathrm{dmft} 2-6$ and age of malnourished children in the study $\left(\mathrm{x}^{2}=54.578\right.$; $\mathrm{p}=0.00$ ), with a positive though moderate correlation between severity of caries experience and age (Spearman's Rho $=0.559 ; \mathrm{p}=0.00$ ). The contingency table for the two variables shows that at higher ages, there is an increase in cases of the categories with caries, and reduction in cases without caries (Table 4).

\section{DISCUSSION}

This study brings to light the problem of ECC in children under six years old diagnosed with child malnutrition in Mendoza, Argentina.

Caries prevalence was $48.2 \%$ when examination included early enamel lesions and $38.2 \%$ when only dentin lesions were considered. Other studies in different parts of the world report different prevalence values. Tsang et al. (2019) report caries prevalence of $58.2 \%$ and a mean value of 3 for the "decayed" component of dmft in populations of malnourished children under 6 years old in $\mathrm{Nepal}^{23}$. Janikaram et al. (2019) report caries prevalence of $33.2 \%$ in similar populations ${ }^{24}$.

It should be highlighted that the values found in the current study are similar to those reported in a previous study on caries prevalence in children under six years old in Mendoza Province. Said study on children with low socioeconomic level in Greater Mendoza reported caries prevalence of 50.2 for enamel and dentin lesions and 35.2 for dentin lesions ${ }^{20}$. Malnourished children constitute 


\begin{tabular}{|c|c|c|c|c|}
\hline & Frequency & $\%$ & Valid \% & Cumulative \% \\
\hline dmft 2-6=0 & 75 & 51.7 & 51.7 & 51.7 \\
\hline dmft 2-6: 1.2 and 3 & 39 & 26.9 & 26.9 & 78.6 \\
\hline dmft 2-6: 4.5 and 6 & 15 & 10.3 & 10.3 & 89.0 \\
\hline dmft 2-6: 7 or more & 16 & 11.0 & 11.0 & 100.0 \\
\hline dmft $4-6=0$ & 93 & 64.1 & 64.1 & 64.1 \\
\hline dmft 4-6:1. 2 and 3 & 37 & 25.5 & 25.5 & 89.7 \\
\hline dmft $4-6: 4.5$ and 6 & 8 & 5.5 & 5.5 & 95.2 \\
\hline dmft $4-6: 7$ or more & 7 & 4.8 & 4.8 & 100.0 \\
\hline
\end{tabular}

Table 3. Dental status expressed through dmft 2-6 and dmfs 2-6 according to age groups in malnourished children in Mendoza.

\begin{tabular}{|c|c|c|c|c|c|c|c|c|c|}
\hline $\begin{array}{l}\text { Age categories } \\
\text { in months }\end{array}$ & Statistics & d t $2-6$ & $m$ t 2-6 & $f t 2-6$ & $\begin{array}{l}\mathrm{dmft} \\
2-6\end{array}$ & d s 2-6 & m s 2-6 & f s 2-6 & $\begin{array}{c}\text { dmfs } \\
2-6\end{array}$ \\
\hline \multirow{5}{*}{$12-23$ months } & Mean & .11 & .00 & .00 & .11 & .11 & .00 & .00 & .11 \\
\hline & Standard error & .066 & .000 & .000 & .066 & .066 & .000 & .000 & .066 \\
\hline & Standard Deviation & .398 & .000 & .000 & .398 & .398 & .000 & .000 & .398 \\
\hline & Rank (Min-max) & $0-2$ & 0 & 0 & $0-2$ & $0-2$ & 0 & 0 & $0-2$ \\
\hline & $\mathrm{N}$ & 36 & 36 & 36 & 36 & 36 & 36 & 36 & 36 \\
\hline \multirow{5}{*}{ 24-35 months } & Mean & 1.38 & .00 & .00 & 1.38 & 1.62 & .00 & .00 & 1.67 \\
\hline & Standard error & .365 & .000 & .000 & .365 & .501 & .000 & .000 & .499 \\
\hline & Standard Deviation & 2.368 & .000 & .000 & 2.368 & 3.246 & .000 & .000 & 3.236 \\
\hline & Rank (Min-max) & $0-12$ & 0 & 0 & $0-12$ & $0-15$ & 0 & 0 & $0-15$ \\
\hline & $\mathrm{N}$ & 42 & 42 & 42 & 42 & 42 & 42 & 42 & 42 \\
\hline \multirow{5}{*}{ 36-47 months } & Mean & 2.41 & .00 & .00 & 2.41 & 2.72 & .00 & .00 & 2.72 \\
\hline & Standard error & .454 & .000 & .000 & .454 & .555 & .000 & .000 & .555 \\
\hline & Standard Deviation & 2.442 & .000 & .000 & 2.442 & 2.987 & .000 & .000 & 2.987 \\
\hline & Rank (Min-max) & $0-8$ & 0 & 0 & $0-8$ & $0-10$ & 0 & 0 & $0-1^{\prime}$ \\
\hline & $\mathrm{N}$ & 19 & 19 & 19 & 19 & 19 & 19 & 19 & 19 \\
\hline \multirow{5}{*}{ 48-71 months } & Mean & 4.29 & .03 & .21 & 4.53 & 7.29 & .13 & .26 & 7.68 \\
\hline & Standard error & .739 & .026 & .094 & .750 & 1.598 & .132 & .117 & 1.604 \\
\hline & Standard Deviation & 4.555 & .162 & .577 & 4.625 & 9.853 & .811 & .724 & 9.889 \\
\hline & Rank (Min-max) & $0-17$ & $0-1$ & $0-2$ & $0-17$ & $0-40$ & $0-5$ & $0-3$ & $0-40$ \\
\hline & $\mathrm{N}$ & 38 & 38 & 38 & 38 & 38 & 38 & 38 & 38 \\
\hline
\end{tabular}

part of the population with low resources, so it is expectable that they would share risk factors with the previously studied population in Mendoza. The similar prevalence values found in the mentioned study can be considered as a reference framework to understand the severity of the problem in this particular epidemiological scenario.

Discrimination of the $\mathrm{dmft}$ index shows that there was a main burden of the decayed component, with very little intervention or treatment, in agreement with other studies ${ }^{24,25}$. This reflects the low demand for dental treatment, and it may be assumed that there are barriers to access to healthcare in common with other child populations, regarding $\mathrm{ECC}^{7}$.

Values for $\mathrm{dmft}$ and $\mathrm{dmfs}$ tended to increase with age, being four times higher in the 48- to 71-month age group than in the 24- to 35-month age group. One study in Nigeria found a similar relation in children with and without malnutrition ${ }^{26}$. In the current study, the difference between dmft 2-6 and dmft 4-6 was statistically significant. It is interesting to note that $31 \%$ of the affected surfaces were enamel lesions, 


\begin{tabular}{|c|c|c|c|c|c|}
\hline \multirow{2}{*}{ Age categories in months } & \multicolumn{4}{|c|}{ Severity dmft 2-6 } & \multirow{2}{*}{ Total } \\
\hline & dmft 2-6=0 & $\begin{array}{c}\text { dmft 2-6: } \\
1.2 .3\end{array}$ & $\begin{array}{c}\text { dmft 2-6: } \\
4.5 .6\end{array}$ & $\begin{array}{c}\text { dmft 2-6: } \\
7 \text { or }+\end{array}$ & \\
\hline $12-23$ months & 33 & 3 & 0 & 0 & 36 \\
\hline 24-35 months & 24 & 13 & 4 & 1 & 42 \\
\hline 36-47 months & 10 & 10 & 6 & 3 & 29 \\
\hline 48-71 months & 8 & 13 & 5 & 12 & 38 \\
\hline Total & 75 & 39 & 15 & 16 & 145 \\
\hline
\end{tabular}

and that in the first year of life, $80 \%$ of the lesions were enamel lesions. Although the caries indicators are not high (as expected for the age), caries onset occurred early in life for the malnourished children in the study.

The severity of caries experience, measured through $4 \mathrm{dmft}$ score categories, for both $\mathrm{dmft} 2-6$ and $\mathrm{dmft}$ 4-6, showed that the most frequent categories were $\mathrm{dmft}=0$ and $\mathrm{dmft}=1,2,3$. However, evaluation of differences between dmft 2-6 and dmft 4-6 showed that when enamel lesions were considered, there was a significant increase in the categories $\mathrm{dmft}=4,5,6$ and $\mathrm{dmft}=7$ or more. One of the aforementioned studies in Nepal also described severity categories according to mean $\mathrm{dmft}$, but considering that among children who only experienced caries, $50 \%$ presented 1 to 4 decayed teeth, $35.3 \%$ had 5 to 9 decayed teeth, and $14.6 \%$ had 10 or more decayed teeth ${ }^{23}$.

It was also found that severity of caries experience increased with age, with a positive though moderate correlation between severity of caries experience and children's age.

These results emphasize the importance of early prevention, detection and treatment of ECC in malnourished children. Timely action is needed to prevent both, pathological and quality of life

\section{ACKNOWLEDGMENTS}

The authors thank the authorities and community of CONIN Mendoza for allowing this study to be performed.

\section{FUNDING}

This study was subsidized by the Secretariat of Research, International and Postgraduate Affairs of Universidad Nacional de Cuyo. Res. 3843/2016-R-K014. complications caused by ECC in children with malnutrition ${ }^{27}$.

The pathological profile for ECC in malnourished children has been described by other authors according to conventional $\mathrm{dmft}$ indicators. One of the contributions of the current study is that addresses the importance of active enamel lesions diagnosed using the ICDAS II system. It also contributes to understanding the behavior of ECC in malnourished children under six years old in Mendoza Province. Because this is a descriptive study focusing only on malnourished children, the limitations in its design do not enable the establishment of possible associations between ECC and nutritional status. These are questions to be addressed in further studies including eutrophic children and other caries risk variables for comparison.

It may be concluded from the results presented that malnourished children under six years old studied in Mendoza had comorbidity with ECC. Dental status worsened with age, showing a high disease burden with little treatment intervention. The values found for caries indicators showed the weight of caries diagnosis in initial stages and the importance of providing systematic preventive and monitoring actions during the early years of malnourished children.

\section{CORRESPONDENCE}

Dra. Claudia N. Fernández

Avelino Maure 31 - Cdad. Mendoza, Argentina. CP 5500

claudia.n.fdz@gmail.com 


\section{REFERENCES}

1. Twetman S. Prevention of Early Childhood Caries (ECC) - Review of literature published 1998-2007. Eur Arch Paediatr Dent 2008;9:12-18.

2. American Academy of Pediatric Dentistry. Definition of ECC Originating Council on Clinical Affair. Review Council. Council on Clinical Affair. Adopted 2003-Revised 2007, 2008, 2010. http://www.aapd.org/media/policies.asp.

3. Wisbaum, W. Coordinado por Collantes S. La desnutrición infantil, Causas, consecuencias y estrategias para su prevención y tratamiento. UNICEF España.2011. https://www.unicef.es/sites/www.unicef.es/files/ Dossierdesnutricion.pdf.

4. Den Besten P, Berkowitz R. Early Childhood Caries: an overview with reference to our experience in California. J Calif Dent Assoc 2003;31:139-143.

5. Congiua G, Campusa G, Luglieb P. Early Childhood Caries (ECC) Prevalence and background factors: a review. Oral Health Prev Dent 2014;1:71-76.

6. Crowe M, O'Sullivan A, McGrath C, Cassetti O, Swords L, O'Sullivan M. Early Childhood Dental Problems: Classification tree analyses of 2 Waves of an infant cohort study. JDR Clin Trans Res 2016;3:275-284.

7. Fernández CN, Squassi AF, Bordoni N. Dental status and dental treatment demands in preschoolers from urban and underprivileged urban areas in Mendoza City, Argentina. Acta Odontol Latinoam 2015;28:3-21.

8. da Fonseca MA. The effects of poverty on children's development and oral health. Pediatr Dent 2012; 34:32-38.

9. Chaves AM, Rosenblatt A, Oliveira OF. Enamel defects and its relation to life course events in primary dentition of Brazilian children: a longitudinal study. Community Dent Health 2007;24:31-36.

10. Mahadevan K, Velavan S. Analysis of salivary proteins as the biochemical indicators of nutritional status and salivary gland function. Int J Pharm Bio Sci 2013; 4: 689-694.

11. Bhaskar D, Satta MM, Jamaluddin MF. Comparison of the chemical composition of normal enamel from exfoliated primary teeth and teeth affected with early childhood caries: an in vitro study. Int J Paediatr Dent 2016; 26: 20-25.

12. Caufield PW, Li Y, Bromage TG. Hypoplasia-associated severe earlychildhood caries - a proposed definition. J Dent Res 2012;91:544-550.

13. Sood S, Ahuja V, Chowdhry S. Reconnoitring the association of nutritional status with oral health in elementary schoolgoing children of Ghaziabad City, North India. J Indian Soc Pedod Prev Dent 2014;32:197-200.

14. Rodrigues Ribeiro T, Shangela da Silva Alves K, de Miranda Mota AC, Pereira Costa D, et al. Caries experience, Mutans Streptococci and total protein concentrations in children with protein-energy undernutrition. Aust Den J 2014;59: 106-113.
15. Ramos-Martinez K, González-Martínez F, Luna-Ricardo L. Oral and nutritional health status in children attending a school in Cartagena, 2009. Rev Salud Publica (Bogota) 2010;12:950-960.

16. Rodríguez PN, Martínez Reinoso J, Gamba CA, Salgado PA et al. Association among salivary flow rate, caries risk and nutritional status in pre-schoolers. Acta Odontol Latinoam 2015;28:185-191.

17. Quintero de Lucas, G. Afecciones bucales en niños desnutridos. Rev Asoc Odontol Argentina 2008; 96: 23-25.

18. Pitts N. "'ICDAS" - an international system for caries detection and assessment being developed to facilitate caries epidemiology, research and appropriate clinical management". Community Dent Health 2004;21:193-198.

19. Hooley M, Skouteris H, Boganin C, Satur J, Kilpatrick $\mathrm{N}$. Body mass index and dental caries in children and adolescents: a systematic review of literature published 2004 to 2011. Syst Rev 2012;1:57. doi: 10.1186/20464053-1-57.

20. Fernández CN, Vuoto ER, Borjas MI, Cambría Ronda $\mathrm{S}$ et al. Frecuencia y severidad de caries de la infancia temprana en niños mendocinos de riesgo social. Revista de la Facultad de Odontología de la UNCuyo. 2018;12:20-26. https://bdigital.uncu.edu.ar/13229

21. WHO Multicentre Growth Reference Study Group. WHO child growth standards based on length/height, weight, and age. Acta Paediatr 2006;450:76-85.

22. WHO: Oral health surveys: Basic methods, Edn 4, Geneva, WHO. 1997.

23. Tsang C, Sokal-Gutierrez K, Patel P, Lewis B et al. Early childhood oral health and nutrition in urban and Rural Nepal. Int J Environ Res Public Health 2019,16:2456.

24. Janakiram C, Antony B, Joseph J. Association of undernutrition and early childhood dental caries. Indian Pediatrics 2018; 55:683-685.

25. Patel N, Gunjana G, Patel S, Thanvi R, Sathvara P, Joshi R. Nutrition and health status of school children in urban area of Ahmedabad, India: comparison with Indian Council of Medical Research and body mass index standards. J Nat Sc Biol Med 2015;6:372-377.

26. Folayan MO, Arije O, Tantawi ME, Kolawole KA, Obiyan $\mathrm{M}$, Arowolo O, Oziegbe EO. Association between early childhood caries and malnutrition in a sub-urban population in Nigeria. BMC Pediatrics 2019;19:433. doi: 10.1186/ s12887-019-1810-2

27. Ending childhood dental caries: WHO implementation manual. Geneva: World Health Organization; 2019. Licence: CC BY-NC-SA 3.0 IGO. URL: http://apps.who. int/iris. 